\title{
UPAYA PERBAIKAN WAKTU KERJA UNTUK MENINGKATKAN PRODUKTIVITAS KERJA ( STUDI KASUS DI PERUSAHAAN OTOMOTIF) KARAWANG
}

\author{
Ade Suhara* \\ Program Studi Teknik Industri \\ Fakultas Teknikdan Ilmu Komputer, Universitas Buana Perjuangan Karawang, 2021
}

\begin{abstract}
ABSTRAK
Suatu perusahaan seringkali dihadapkan pada suatu permasalahan yang berkaitan dengan upaya pencapaian target produksi. Saat ini, perusahaansedang menitik beratkan pada proses perakitan, proses produksi yang dilakukannya masih sering dilakukan proses repair terhadap produk akhir. Proses repair tersebut tentunya akan mengakibatkan hilangnya waktu produksi dan keterlambatan pendistribusian produk.

Meningkatnya grafik produk reject merupakan suatu indikasi adanya kehilangan waktu kerjayang akan menyebabkan turunnya tingkat produktivitas yang berakhir pada menurunnya tingkat profit dari yang ditargetkan. Salah satu langkah yang harus dilakukan adalah melakukan perbaikan sistem kerja pada tiap-tiap stasiun kerja. Proses yang dilakukan perbaikan waktu kerja ini adalah dengan membuat peta-peta kerja, yang terdiri dari; Peta Aliran Proses, Peta PekerjaMesin, dan Peta Tangan Kiri dan Tangan Kanan; Pengukuran waktu (Time Study) dengan mengambil jenis pengukuran waktu secara langsung dengan menggunakan metode jam henti (Stopwatch) dan sampling pekerjaan; Perancangan dan perbaikan sistem kerja dengan menggunakan studi gerakan, SMED, 7 tool; dan Perhitungan waktu kerja yang dihasilkan dijadikan bahan rujukan pembuatan Standard Operational Procedure (SOP) yang merupakan SOP perbaikan dari SOP sebelumnya.
\end{abstract}

Kata Kunci : Kondisi Perusahaan, Waktu Kerja, Perbaikan Sistem Kerja

\section{PENDAHULUAN}

Suatu perusahaan seringkali dihadapkan pada suatu permasalahan yang berkaitan dengan upaya pencapaian target produksi baik dari segi kuantitas terlebih lagi dari segi kualitas produk. Hal ini dapat terjadi diantaranya diakibatkan oleh adanya kerusakan pada produk yang dihasilkan dan ketepatan waktu produksi. Banyaknya produk yang rusak atau cacat tersebut menyebabkan sebagian hasil produksi harus dijual di bawah harga standar atau perusahaan yang bersangkutan khususnya departemen yang memproduksi produk tersebut harus melakukan proses produksi ulang apabila produk tersebut masih bisa diupayakan untuk itu, yang mengakibatkan meningkatnya waktu silklus produksi yang dibutuhkan dengan berakhir pada naiknya biaya produksi ( production cost), sehingga target produksi dengan keuntungan ( profit ) yang diharapkan tidak dapat tercapai sesuai standar yang telah ditetapkan. Selain itu, tidak sedikit customer membatalkan kontrak pembelian barang dikarenakan terlambatnya pengiriman produk pesanannya. 
Agar hal tersebut tidak terjadi secara terus-menerus, maka harus dicari faktor-faktor penyebab timbulnya permasalahan tersebut, dan kemudian dilakukan sebuah analisis untuk perbaikan di masa yang akan datang dengan memberikan penjabaran upaya menurunkan jumlah produk reject dengan melakukan perbaikan sistem untuk meminimasi kehilangan waktu kerja, yang mengarah pada tingkat efisiensi proses produksi, khususnya pada pada departemen produksi.

\section{TINJAUAN PUSTAKA}

\section{1 Teknik Tata Cara Kerja}

Teknik tata cara kerja adalah suatu ilmu yang terdiri dari teknik - teknik dan prinsipprinsip untuk mendapatkan rancangan terbaik dari sistem kerja (Sutalaksana, dkk,1979). Teknik-teknik dan prinsip-prinsip ini digunakan untuk mengatur komponen-komponen sistem kerja yang terdiri dari manusia dengan sifat dan kemampuannya, bahan, perlengkapan dan peralatan kerja, serta lingkungan kerja sedemikian rupa sehingga dicapai tingkat efisiensi dan produktifitas yang tinggi.

\subsection{Peta - Peta Kerja}

Peta kerja adalah salah satu alat komunikasi yang sistematis dan jelas, bahkan informasi yang terkandung dalam suatu peta kerja dapat dipakai sebagai bahan untuk merancang atau memperbaiki sistem kerja (Sutalaksana, dkk, 1979). Dengan peta kerja, dapat dilihat semua langkah atau kegiatan yang dialami suatu obyek (benda kerja) sejak awal proses, sampai pada proses menghasilkan produk.

\subsection{Ergonomi}

Ergonomi ialah suatu cabang ilmu yang sistematis untuk memanfaatkan informasiinformasi mengenai sifat, kemampuan, dan keterbatasan manusia untuk merancang suatu sistem kerja sehingga orang dapat hidup dan bekerja pada sistem itu dengan baik, yaitu mencapai tujuan yang diinginkan melalui pekerjaan itu dengan efektif, aman dan nyaman (Sutalaksana, dkk, 1979).

\subsection{Studi Gerakan}

Studi gerakan adalah analisa yang dilakukan terhadap beberapa gerakan badan pekerja dalam menyelesaikan pekerjaannya. Dengan demikian diharapkan agar gerakangerakan yang tidak efektif dapat dikurangi bahkan dihilangkan sehingga akan diperoleh penghematan dalam waktu kerja, yang selanjutnya dapat pula menghemat pemakaian fasilitas-fasilitas yang tersedia untuk pekerjaan tersebut (Sutalaksana, dkk, 1979).

\subsection{Prinsip-Prinsip Ekonomi Gerakan}

Untuk mendapatkan hasil kerja yang baik, tentu diperlukan perancangan sistem kerja yang baik pula. Oleh karena itu sistem kerja yang harus dirancang sedemikian rupa sehingga dapat memungkinkan dilakukan gerakan-gerakan yang ekonomis. Prinsip-prinsip 
ekonomi gerakan dapat dibagi menjadi tiga bagian, yakni dihubungkan dengan tubuh manusia dan gerakannya, pengaturan tata letak tempat kerja, dan perancangan peralatan.

\subsection{Pengukuran Waktu}

Pengukuran waktu merupakan usaha untuk menentukan lamanya waktu kerja yang dibutuhkan operator (yang terlatih) untuk menyelesaikan suatu pekerjaan yang spesifik, pada tingkat kecepatan kerja yang normal, dalam lingkungan kerja yang terbaik (Sutalakasana, dkk, 1979).

Pengukuran waktu kerja dapat dilakukan secara langsung yaitu dengan jam henti dan sampling pekerjaan, secara tidak langsung yaitu dengan menggunakan data waktu baku dan data waktu gerakan, yakni dengan metode Work Factor, MOST, MTM, dan lain-lain.

Teknik pengukuran yang digunakan harus sesuai dengan karakteristik sistem kerja, misalnya untuk jam henti jenis pekerjaan harus homogen, dilakukan secara berulang-ulang dan sejenis serta terdapat output yang riil berupa produk yang dapat dinyatakan secara kuantitatif.

Langkah-langlah yang dilakukan sebelum pengukuran waktu kerja adalah:

- Penetapan tujuan pengukuran

- Melakukan penelitian pendahuluan

- Memilih operator

- Melatih operator

- Mengurangi pekerjaan atas elemen pekerjaan

- Menyiapkan alat-alat pengukuran

Langkah selanjutnya adalah melakukan pengukuran waktu kerja setelah itu harus dilakuakan uji statistik antara lain uji kenormalan, uji keseragaman, dan uji kecukupan data. Kemudian apabila sudah memenuhi ketiga uji tersebut kita hitung waktu siklus, waktu normal dan waktu bakunya.

\section{METODOLOGI PENELITIAN}

\subsection{Langkah- langkah Penelitian}

\section{Identifikasi Masalah}

Masalah yang terjadi adalah kondisi saat ini PT. Kanzen dalam segi kualitas serta pola permintaan (Market Share) masih bisa bersaing dengan perusahaan sejenis, namun perubahan trend dan pertambahan jumlah pesaing masih harus diperhitungkan, peningkatan efesiensi terutama di bidang produksi senantiasa harus dilakukan.

\section{Studi Pustaka}

Studi pustaka dilakukan untuk memperoleh informasi yang diperlukan sebagai landasan berpikir bagi penelitian yang akan dilakukan informasi-informasi ini diperoleh dari berbagai literatur yang berhubungan dengan topik penelitian. Dengan dilakukannya studi pustaka ini diharapkan penelitian yang dilakukan menjadi sistematis serta terarah. 


\section{Pengumpulan Data}

Pengumpulan data bertujuan untuk mengumpulkan data yang diperlukan sebagai bahan analisis. Jalan yang ditempuh untuk memperoleh data ini adalah dengan pengamatan langsung, wawancara dengan pihak terkait, serta dengan melakukan pencatatan ataupun pengukuran data. Dimana data penelitian dibedakan menjadi 2, yaitu:

- Data umum

- Data Penelitian

- Populasi dan sample penelitian

\section{Pengolahan Data}

Pengolahan data untuk memecahkan masalh ini adalah dengan menggunakan data waktu proses per elemen kerja (peta tangan kanan tangan kiri \& peta kerja keseluruhan), kondisi lingkungan, tata letak fasilitas, waktu standart, dan analisa tingkat produktivitas.

\section{Analisa dan Pembahasan}

Analisis yang dilakukan diarahkan pada pengidentikasian masalah-masalah yang ada di stasiun kerja sebagai obyek penelitian. Pengidentifikasian masalah diawali dari identifikasi masalah yang timbul di stasiun kerja yang diasumsikan sebagai stasiun kerja yang paling banyak menimbulkan kecacatan produk.

\section{Kesimpulan dan Saran}

Penelitian ini akan diakhiri dengan penarikan kesimpulan berdasarkan pengolahan data dan analisis yang telah dilakukan. Setelah itu akan diajukan saran-saran yang diharapkan dapat bermanfaat, khususnya bagi perusahaan dimana penelitian dilakukan.

\subsection{Langkah - langkah dalam melakukan perbaikan system kerja pada tiap - tiap stasiun kerja}

Meningkatnya grafik produk reject yang masuk pada unit repair merupakan suatu parameter adanya production lost time yang akan menyebabkan turunnya tingkat produktivitas yang berakhir pada mahalnya harga produk karena biaya produksi tinggi atau menurunnya tingkat profit dari yang ditargetkan. Salah satu langkah yang harus dilakukan adalah melakukan perbaikan sistem kerja pada tiap-tiap stasiun kerja.

Permasalahan yang dimunginkan timbul di lapangan dapat di analisis dari beberapa aspek, diantaranya:

1. Mata rantai sistem kerja unit produksi

Hal ini dimaksudkan untuk mengetahui sistem kerja unit produksi mencakup mata rantai aktivitas pekerjaan assembling.

Pekerjaan serta urutan-urutan proses kerja dapat digambarkan dalam aliran seperti gambar dibawah ini: 


\begin{tabular}{|c|c|c|c|}
\hline $\begin{array}{c}\text { Stasiun Kerja } \\
\text { Assy. I }\end{array}$ & $\begin{array}{c}\text { Stasiun Kerja } \\
\text { Assy. II }\end{array}$ & $\begin{array}{c}\text { Stasiun Kerja } \\
\text { Assy. III }\end{array}$ & $\begin{array}{c}\text { Stasiun Kerja } \\
\text { Assy. IV }\end{array}$ \\
\hline $\begin{array}{l}\text { Stasiun Kerja } \\
\text { Assy.VIII }\end{array}$ & $\begin{array}{c}\text { Stasiun Kerja } \\
\text { Assy. VII }\end{array}$ & $\begin{array}{c}\text { Stasiun Kerja } \\
\text { Assy. VI }\end{array}$ & $\begin{array}{c}\text { Stasiun Kerja } \\
\text { Assy. V }\end{array}$ \\
\hline $\begin{array}{c}\text { Stasiun Kerja } \\
\text { Assy. IX }\end{array}$ & $\begin{array}{c}\text { Stasiun Kerja } \\
\text { Assy. X }\end{array}$ & $\begin{array}{c}\text { Stasiun Kerja } \\
\text { Assy. XI }\end{array}$ & $\begin{array}{c}\text { Stasiun Kerja } \\
\text { Assy. XII }\end{array}$ \\
\hline & & $\begin{array}{c}\text { Stasiun Kerja } \\
\text { Assy. XIV }\end{array}$ & $\begin{array}{c}\text { Stasiun Kerja } \\
\text { Assy. XIII }\end{array}$ \\
\hline
\end{tabular}

2. Tata letak urutan kerja

Maksud dari tata letak urutan kerja adalah meminimasi jarak transportasi untuk penanganan material, orang maupun barang, mencakup perubahan daerah produksi secara keseluruhan. Dengan cara menyesuaikan aliran proses, waktu proses, dan kondisi ruangan area yang ada berdasarkan nilai ekonomisnya.

3. Analisa dan perbaikan sistem kerja pada setiap stasiun kerja

Hal ini dimaksudkan untuk meningkatkan efisiensi, efektifitas serta produktivitas dari masing-masing stasiun kerja. Adapun perbaikan pada sistem kerja pada 5 faktor utama, diantaranya:

a. Man (operator)

Pada setiap stasiun kerja keterampilan operator dalam menyelesaikan aktivitasnya ditingkatkan dengan pelatihan metoda yang tepat serta kecekatan dalam prakteknya.

b. Machine (Fasilitas)

Mesin serta fasilitas yang ada disesuaikan dengan kebutuhan operator serta ukuranukran alat dirancang sesuai dengan ukuran-ukuran tubuh manusia (bio mekanika).

c. Material

Bahan yang berupa spare part dan bahan pembantu lainya selain itu dalam pengadaan perlu diperhatikan untuk mempercepat proses yang dilakukan.

d. Metoda operasi

Metoda dalam operasi disesuaikan dengan berbagai model yang diproduksi, walaupun pada dasarnya perbedaan tiap model tidak terlalu significant namun hal tersebut dapat dikhususkan terhadap pekerja-pekerja tertentu.

e. Kondisi lingkungan

Lima komponen dasar yang membentuk lingkungan termal adalah temperatur, kelembaban, temperatur permukaan sekitar, pergerakan udara dan kualitas udara.

1. Temperatur

2. Tingkat pencahayaan

3. Tingkat kebisingan 


\section{Pengumpulan Dan Pengolahan Data}

\subsection{Pengumpulan Data}

Data yang dibutuhkan dalam pengumpulan data yaitu sebagi berikut:

1. SOP Stasiun Kerja Perakitan Sprocket, Setting Chain Drive \& Rear Wheel

2. Waktu penyelesaian produk

3. Tatat letak stasiun kerja sekarang

4. Peta - peta kerja

5. Pengamatn hasil pekerjaan

\subsection{Pengolahan Data}

Pengolahan data dalam penelitian tini yaitu sebagai berikut :

\subsubsection{Diagram Pareto}

Bila digambarkan dengan diagram Pareto maka tampilannya adalah sebagai berikut:

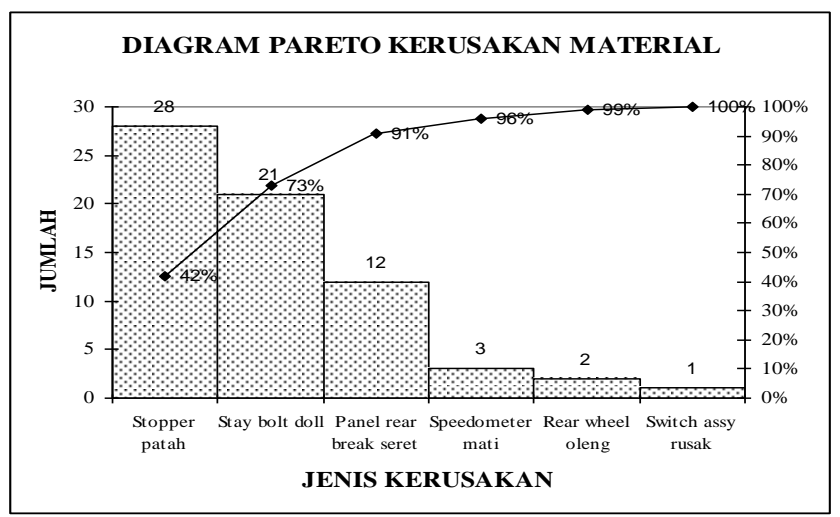

Gambar 4.3 Diagram Pareto Untuk Jumlah \& Jenis Kerusakan

\subsubsection{Sampling Pekerjaan}

Adapun lembaran hasil pengamatan sampling pekerjaan dapat dilihat pada lampiran $\mathrm{G}$ berikut rekapitulasi hasil pengamatan sampling. Dari lembar pengamatan sampling dapat diketahui aktivitas produktif dan non produktif operator, hasil pengamatan diperoleh hasil pengukuran sebagai berikut:

\begin{tabular}{|c|l|c|c|c|c|c|c|}
\hline \multirow{2}{*}{ NO } & \multirow{2}{*}{ KEGIATAN } & \multicolumn{5}{|c|}{ FREKUENSI } & \multirow{2}{*}{ JUMLAH } \\
\cline { 3 - 7 } & & 1 & 2 & 3 & 4 & 5 & \\
\hline \hline 1 & Produktif & 54 & 54 & 54 & 55 & 54 & 271 \\
\hline 2 & Non Produktif & 2 & 2 & 2 & 1 & 2 & 9 \\
\hline 3 & Jumlah & 56 & 56 & 56 & 56 & 56 & 280 \\
\hline 4 & \% Produktif & 96 & 96 & 96 & 98 & 96 & 96,8 \\
\hline
\end{tabular}




\subsubsection{Uji Data}

A. Pengujian Keseragaman Data

Dari tabel 4.3 dengan 5 hari pengamatan dapat diketahui:

$$
\begin{aligned}
\mathrm{P}=\frac{484}{5} & =96,8 \\
\mathrm{BKA} & =\mathrm{P}+\mathrm{Z}_{\alpha / 2} \sqrt{\mathrm{P} \frac{(1-\mathrm{P})}{\mathrm{n}}} \\
& =0,968+1,880 \sqrt{0,968 \frac{(1-0,968)}{56}} \\
& =1,012 \\
& =\mathrm{PKB}-\mathrm{Z}_{\alpha / 2} \sqrt{\mathrm{P} \frac{(1-\mathrm{P})}{\mathrm{n}}} \\
& =0,968-1,880 \sqrt{0,968 \frac{(1-0,968)}{56}} \\
& =0,924
\end{aligned}
$$

Dari angka di atas dapat disimpulkan bahwa data berada di dalam batas kontrol, maka data dinyatakan seragam.

B. Pengujian Kecukupan Data

Setelah data dinyatakan seragam, yang perlu dilakukan adalah pengujian kecukupan data. Perhitungan kecukupan data dari pengamatan yang dilakukan adalah sebagai berikut :

$$
\begin{aligned}
\mathrm{N}^{\prime} & =1600 \frac{(1-\mathrm{P})}{\mathrm{P}} \\
& =1600 \frac{(1-0,968)}{0,968} \\
& =53,14 \rightarrow 53
\end{aligned}
$$

Kesimpulan N'< N, maka kecukupan data telah terpenuhi.

C. Menentukan Faktor Penyesuaian

Menentukan faktor penyesuaian dengan menggunakan metode Shumard, peneliti menilai yang diamati tergolong pada kelas good + dan penyesuaiannnya pada tabel penyesuaian yaitu dengan nilai 75. (sumber dari: Sutalaksana, dkk, Teknik Tata Cara Kerja,1979).

Maka diperoleh faktor penyesuaiannya adalah : 
Good $+=\frac{75}{60}=1,25$

Sebagai bahan perbandingan peneliti menyajikan penentuan faktor penyeseuaian dengan metode oyektif, dimana pada metode ini diperhatikan 2 faktor yaitu kecepatan kerja dan tingkat kesulitan pekerjaan. Kedua faktor inilah yang dipandang secara bersama-sama menentukan berapa harga $\mathrm{P}$ untuk mendapatkan waktu normal.

4.2.4 Perhitungan tingkat produktivitas untukPerbandingan Waktu kondisi sekarang dengan waktu usulan

1. Waktu Kondisi Sekarang

Waktu kondisi sekarang adalah waktu kerja yang diambil berdasarkan pengukuran langsung sebelum dilakukan usulan perbaikan dengan penyesuaian dan kelonggaran berdasarkan jenis pekerjaanya.

Waktu kondisi sekarang = waktu proses kondisi sekarang + faktor penyesuaian dan kelonggaran

Waktu proses (Wp) adalah waktu yang digunakan untuk penyelesaian membuat pola satu proses. Wp sekarang $=98.3$ detik. Dengan faktor penyesuaian dan kelonggaran yang telah dihitung di awal pembahasan, yaitu masing-masing $\mathrm{P}=$ 1.78 dan $\mathrm{L}=0.54$, maka waktu normalnya adalah

Waktu normal $=98.3 \times 1.78 \quad=174,974$ detik

Waktu baku $\quad=174.974+(174.974 \times 0.54)=269.46$ detik

2. Waktu standart

Waktu standart adalah waktu kerja yang ditetapkan yang telah disesuaikan dengan faktor penyesuaian dan kelonggaran berdasarkan jenis pekerjaanya.

Waktu standart $(\mathrm{Ws})$ kondisi usulan = waktu proses + faktor penyesuaian dan kelonggaran.

Waktu proses yang diusulkan oleh pengukur adalah 86.9 detik, maka diperoleh waktu standar adalah :

Waktu normal $\quad=86,9 \times 1.78=154.7$ detik

Waktu baku $\quad=154.7+(154.7 \times 0.54)=238.3$ detik

3. Perhitungan Tingkat Produktivitas

Perhitungan tingkat produktivitas untuk perbandingan antara waktu kondisi sekarang dan waktu kondisi usulan maka perlu dibuatkan perhitungan sebagai berikut :

Total waktu kondisi sekarang $=296.46$ detik

Total waktu kondisi usulan $\quad=\quad 238.3$ detik 
7 jam kerja

Kondisi sekarang

Kondisi usulan

Jadi tingkat produktivitas naik =

$$
\begin{array}{lll}
= & 420 \text { menit } & =25200 \text { detik } \\
= & 25200 / 296.46 & =85 \text { unit } / \text { hari kerja } \\
= & 25200 / 238.3=106 \text { unit } / \text { hari kerja } \\
= & 106-85 \quad=21 \text { unit } / \text { hari kerj }
\end{array}
$$

\section{Analisa Dan Pembahasan \\ 5.1 Analisa}

Pada penelitian ini analisa dilakukan pada beberapa hal, diantaranya sebagai berikut:

1. Analisa Peta - Peta Kerja

2. Analisa Tata Letak Stasiun Kerja

3. Analisa Perbaikan Waktu Kerja

Tabel 5.1 Perbandingan Waktu Kondisi Sekarang dan Waktu Usulan

\begin{tabular}{|l|c|c|c|}
\hline \multicolumn{1}{|c|}{ Keterangan } & $\begin{array}{c}\text { Kondisi Sekarang } \\
\text { (detik) }\end{array}$ & $\begin{array}{c}\text { Hasil Usulan } \\
\text { (detik) }\end{array}$ & $\begin{array}{c}\text { Selisih Waktu } \\
\text { (detik) }\end{array}$ \\
\hline \hline Waktu proses & 98.3 & 86.9 & 11.4 \\
\hline Waktu normal & 174.974 & 154.7 & 20.274 \\
\hline Waktu baku & 269.46 & 238.3 & 31.16 \\
\hline
\end{tabular}

Dalam produktivitas ini dilakukan dalam satuan unit assembling dalam kurun waktu satu hari ( 7 jam kerja $=60 \times 7=420$ menit $)$.

Dimana tingkat produktivitas dapat dilihat sebagai berikut :

Jumlah jam kerja $=7$ jam $=420$ menit $=25200$ detik

Produktivitas sekarang $\quad=25200 / 269.46=85$ unit $/$ hari kerja

Produktivitas usulan $\quad=25200 / 238.30=106$ unit $/$ hari kerja

Selisih produktivitas $=106-85=21$ unit $/$ hari kerja

\subsection{Pembahasan}

1. Perbaikan Waktu Kerja

Waktu kerja kondisi sekarang merupakan waktu proses pada awal penelitian yang kemudian dianalisa untuk diperbaiki sesuai gerakan yang diperlukan dengan metode yang lebih baik serta penempatan peralatan maupun bahan yang akan digunakan sehingga dapat mengurangi waktu proses 
2. Tingkat Produktivitas

Dalam produktivitas ini dilakukan dalam satuan unit assembling dalam kurun waktu satu hari ( 7 jam kerja $=60 \times 7=420$ menit ).

Dimana tingkat produktivitas dapat dilihat sebagai berikut :

Jumlah jam kerja $=7$ jam $=420$ menit $=25200$ detik

Produktivitas sekarang $\quad=25200 / 269.46=85$ unit $/$ hari kerja

Produktivitas usulan $\quad=25200 / 238.30=106$ unit $/$ hari kerja

Selisih produktivitas $=106-85=21$ unit $/$ hari kerja

Dengan demikian persentase kenaikan produktivitasnya adalah :

( $21 / 85$ ) x 100\% = $24.7 \%$, angka yang signifikan.

\section{Kesimpulan Dan Saran}

\subsection{Kesimpulan}

- Waktu Standar

Sesuai dengan nilai-nilai yang telah ditentukan berdasarkan metode ini kemudian diberikan faktor penyesuaian dan waktu kelonggaran sesuai lingkungan dan kebutuhan pribadi dari pekerja dan diperoleh waktu baku untuk perakitan 1 unit produk adalah 238.3 detik yang awalnya 296.46 detik.

- Tingkat Produktivitas

Jumlah jam kerja $=7$ jam $=420$ menit $=25200$ detik

Produktivitas sekarang $\quad=25200 / 269.46=85$ unit $/$ hari kerja

Produktivitas usulan $\quad=25200 / 238.30=106$ unit $/$ hari kerja

Selisih produktivitas $=106-85=21$ unit $/$ hari kerja

Dengan demikian persentase kenaikan produktivitasnya adalah :

$(21 / 85) \times 100 \%=24.7 \%$, angka yang signifikan.

Berarti dapat diketahui terjadi kenaikan tingkat produktivitas 21 unit atau $24.7 \%$ per hari, tentunya hal itu harus didukung dengan

\subsection{Saran}

1.Pemberian pemahaman dan kesadaran kepada semua pihak yang terlibat langsung maupun tidak langsung dalam proses pembuatan produk akan pentingnya upaya perbaikan sistem waktu kerja.

2.Penerapan prinsip-prinsip 5S. (Sumber : Takasi Osaba, Sikap kerja 5S. Jakarta : Penerbit PPM. 2002)

3.Perubahan tata letak, baik fasilitas unit produksi maupun tata letak masing-masing stasiun kerja.

4.Pelatihan sistem kerja baru pada karyawan, operator dan pihak manajemen.

5.Evaluasi hasil penerapan sistem kerja baru. 


\section{DAFTAR PUSTAKA}

1. Barnes, R.M. Motion and Time Stuty. Design and Measurement of Work. New york : John Wiley \& Son, Inc, 1980

2. Modul Praktikum Perancangan Sistem Kerja \& Ergonomi. Laboratorium Perancangan Sistem Kerja \& Ergonomi.

3. Dr. Dradjat Suhardjo, SU. Metodologi Penelitian \& Penulisan Laporan Ilmiah. Yogyakarta : Penerbit Perpustakaan Nasional RI, Katalog dalam terbitan (KDT)

4. Sutalaksana, Iftikar Z. Teknik Tata Cara Kerja. Bandung : Penerbit ITB. 1979

5. Dra. Sedarmayanti M.Pd. Tata Kerja dan Produktivitas Kerja. Bandung : Penerbit CV. Mandar Maju . 1996.

6. Takashi Osada. Sikap Kerja 5S. Jakarta : Penerbit PPM. 2002. 